\title{
A TRAJETÓRIA DE GEORGE SAND E AS MOVIMENTAÇÕES PARA A CONQUISTA DE UMA POSIÇÃO DE LEGITIMIDADE NO CAMPO LITERÁRIO
}

Daiane Basílio de Oliveira

Resumo: Um dos grandes empecilhos erigidos contra a produção literária das mulheres, entre elas a francesa George Sand, se assenta nas disputas do campo literário, no qual as relações de força entre as instâncias que o compõe intervêm na produção e circulação das obras literárias. Sustentado na noção de que a produção literária de um escritor é formulada em um processo interativo, a proposta de estudo da trajetória literária de George Sand parte do imperativo de interpretar sua matriz biográfica, erudita e profissional, as estratégias utilizadas e a maneira como a escritora oitocentista alcançou status de legitimidade no campo literário francês. Sua trajetória revela uma série de posições no campo literário que estão vinculados à projeção de diferentes ou repetidos ethe formulados em seu projeto de criação literária, os quais revelam as movimentações da escritora em busca de uma posição de legitimidade. Assim, em conformidade com a teoria do campo literário de Bourdieu (1996), busca-se compreender os aspectos que guiaram no sentindo de marcar época e se estabelecer na vanguarda do campo literário francês: os valores incorporados e investidos, os capitais, as suas sucessivas movimentações de posição e escolhas enunciativas, bem como mapear suas relações com os agentes do campo literário.

Palavras-chave: George Sand. Literatura francesa. Campo literário. Trajetória. Ethos.

Resumé: L'un des grands obstacles contre la production littéraire des femmes, parmi lesquelles la Française George Sand, repose sur des disputes dans le champ littéraire, dans lesquel les rapports de force entre les instances qui le composent interviennent dans la production et la circulation des œuvres littéraires. À partir de l'idée que la production littéraire d'un écrivain est formulée dans un processus intéractif, la proposition d'étudier la trajectoire littéraire de George Sand parvient l'impératif d'interpréter sa matrice biographique, érudite et professionnelle, les stratégies utilisées et la façon dont l'écrivaine du XIXe siècle a accédé au statut de légitimité dans le champ littéraire 
français. Sa trajectoire révèle une série de positions dans le champ littéraire liées à la projection d'éthe différents ou répétés dans son projet de création littéraire qui révèlent ses mouvements à la recherche d'une position de légitimité. Ainsi, d'après la théorie du champ littéraire de Bourdieu (1996) et de l'éthos discursif de Maingueneau (2006), le but est-il de comprendre les aspects qui ont guidé le sentiment de marquer une époque et de s'installer dans l'avant-garde du champ littéraire français: les valeurs incorporées et investies, les capitaux, leurs mouvements successifs de position et de choix énonciatifs, ainsi que leurs relations avec les agents du champ littéraire.

Mots-clés: George Sand. Littérature française. Champ littéraire. Trajectoire. Ethos.

\section{INTRODUÇÃO}

Aurore Amandine Lucile Dupin, verdadeiro nome da escritora George Sand, foi uma romancista, crítica literária, dramaturga, ensaísta e jornalista que nasceu em Paris em julho de 1804 e faleceu em Nohant em junho de 1876. Como uma das representantes da literatura francesa do século XIX, desempenhou importante papel na vida política de sua época, principalmente por representar ideias de cunho sociopolítico e em prol das mulheres em seu projeto de criação literária.

Num arco temporal de mais de quatro décadas, a participação de George Sand no campo literário foi marcada pelo grande número de romances, novelas e contos publicados, enfrentamentos e escândalos causados pelo teor de suas publicações contra hegemônicas e por 
seu modo de agir, vestimentas e envolvimentos afetivos pouco ortodoxos para época.

Ao observar o projeto de criação literária da escritora e a sua consolidação, questionam-se os mecanismos e as estratégias por ela empenhados para acessar a posição de autoridade e legitimidade no campo literário, espaço social que assim como os demais fora criado e estruturado com vista à participação e domínio masculino. Em resposta, a investigação acerca da trajetória de George Sand no campo literário, de acordo com a gênese do campo proposta por Pierre Bourdieu (1996), envolve as estruturas das relações estabelecidas neste campo principalmente com os editores, os habitus e as posições da escritora que determinam as boas e más escolhas na escrita de suas obras literárias e sua permanência na anamnese literária.

Assim, neste artigo pretende-se descortinar questões pertinentes ao estabelecimento de Sand no campo literário francês de sua época, tendo em vista os impedimentos impostos às mulheres que desejavam viver sob a pluma, e as estratégias que sustentam a sua carreira, as quais considerando o contexto de produção reverberam em seu discurso literário. 


\section{CAMPO LITERÁRIO E TRAJETÓRIA SEGUNDO BOURDIEU}

O arcabouço teórico e metodológico do sociólogo francês Pierre Bourdieu em As Regras da Arte (1996a) compreende a obra de arte em relação ao campo de produção de bens culturais. O estudioso realiza um trabalho voltado para a literatura com a intenção de superar a querela das correntes críticas e se lançar em uma leitura sociológica que tenciona abordar as determinantes e os parâmetros que agem na esfera cultural.

Bourdieu (1996a) aprofunda a discussão sobre a configuração simbólica da realidade e propõe um modelo de análise correlativa entre o campo literário e o campo do poder. Ao delinear as relações existentes entre um criador de um projeto artístico e intelectual - a exemplo de George Sand - Bourdieu estabelece sua base teórica sobre o campo literário e suas engrenagens. O objetivo principal se assenta num estudo sociológico quanto às relações de força que se instauram entre as instâncias que compõem o campo literário e de quais maneiras elas intervêm sobre a produção e circulação das obras literárias.

O conceito de campo se sobrepõe ao de sociedade, posto que esta não é vista como um todo integrado que funciona organicamente, mas, como fundada por um conjunto de 
microcosmos sociais providos de uma autonomia. Assim, o campo é condicionado a lógicas e perspectivas particulares, pautado em propensões, interesses e disputas internas e irredutíveis ao funcionamento de qualquer outro campo. O campo é, por isso, um núcleo marcado por disputas e relações de poder.

A consistência teórica do conceito de campo se explica por uma dinâmica autônoma, que traz em si mesma as condições de seu próprio funcionamento, com suas instâncias de consagração, vozes autorizadoras, definição do que é legitimo e luta concorrencial. Assim, ao se tratar da existência do campo literário, devem-se considerar os elementos ativos do campo, seus agentes: escritores, editores, leitores, críticos, entre outros são enquadrados em uma lógica interativa e relacional.

Na França do século XIX, o universo de produção artística passou pelo processo de autonomização que se deu a partir de três condições: o aparecimento de escritores especializados; as instâncias de legitimação; e a emergência de um mercado. A autonomização do campo literário figura, então, como produto de uma reação contra o mercado, as pressões econômicas, as sanções estatais e a intervenção do sistema religioso. Essa estruturação do 
espaço literário pautada na defesa da liberdade de criação avessa aos sistemas de poder chancela a presença de um campo literário relativamente autônomo.

Esse processo está relacionado, também, à contrariedade às censuras ideológicas, morais e políticas sobre a literatura. Tal autonomia é assumida não somente em oposição a uma lógica mercadológica, é efetivada também por meio de embates contra as responsabilidades penais aplicadas aos escritores e as definições sociais do oficio de escritor que se opunham à liberdade de criação. Sapiro (2013, p. 9) explica que essa patente de responsabilidade autoral ultrapassava as fronteiras do mundo das letras, impondo normas a diversos campos.

A atividade literária não era considerada profissão, era necessário que houvesse uma relação de ensinoaprendizagem ou título acadêmico para que tal reconhecimento fosse legitimado, o que não era o caso dos escritores. Esta época foi marcada pelo surgimento do mercado do livro que pode ser interpretado segundo observação relacional, de um lado os escritores dominados que produzem com alguma remuneração sob o regime de autorizações prévias e o domínio de livreiros, e do outro os escritores que ocupam posições dominantes, os quais 
são mantidos pelo poder em cargos e funções oficiais. É a partir do mercado do livro que os escritores começam a se distanciar da regulamentação do Estado e da Academia que fazia juízo de valor sobre os bens artísticos independente das legislações da Igreja e da prática do clientelismo. E a ascensão do mercado do livro pode ser interpretada sob a ótica dessa observação relacional.

É plausível inferir que a gênese do conceito de campo foi pensada a partir da necessidade de reunir em um mesmo espaço os agentes que compartilham de habitus semelhantes na esfera social. Bourdieu (1996b, p. 21) destaca que o habitus é a incorporação das disposições sociais por um grupo e/ou indivíduo, e é adquirido conforme o campo em que os agentes estão inseridos, gerando posições de acordo com as escolhas. "O habitus é esse princípio gerador e unificador que retraduz as características intrínsecas e relacionais de uma posição em um estilo de vida unívoco, isto é, em conjunto unívoco de escolhas, de bens, de práticas" (BOURDIEU, 1996b, p. 21).

Ele é uma categoria operante que torna possível a comunicação entre as estruturas objetivas e as práticas. Por exemplo, ao se pensar na atividade literária, as práticas discursivas são resultado da interação dialética entre o 
circunstancial e um habitus. Por isso, ele é o efeito da interiorização de estruturas, as práticas dos agentes as exteriorizam e permitem perceber quais foram acionadas e incorporadas. A atuação do habitus se encontra no cerne da organização das ações, podendo ser ou não esquematizadas em detrimento de um propósito estratégico.

Voltando-se para o campo literário, o habitus configura os regulamentos práticos investidos em sua ação e do mesmo modo reproduz as estruturas de organização do campo: o que é escrito e publicado, quem é dominante e quem é dominado, quem possui ou não legitimidade, são esquemas e princípios classificatórios que estabelecem as diferenças em conformidade com os valores incorporados por cada um. "O habitus, assim, responde pelo pólo da ação e, mais modestamente, pela criatividade e pela memória social" (DOMINGUES, 2001, p. 59). Isto é, ele conserva a memória e a ação, e assim alimenta o dispositivo criador, desse modo, se encarrega de propiciar a atividade criadora e sua unicidade criativa.

Nestes termos, um romance a exemplo de Lélia foi compreendido por seu editor Henri Dupuy como uma obra distinta e digna de ser publicada por, talvez, ser carregada de relevantes reflexões filosóficas e liberais, enquanto que para 
outros agentes do campo foi julgado sob um polo negativo. Essa reprovação pode se estender a outros campos, tendo em vista o público leitor, e não por acaso o romance foi censurado pelo campo religioso e anexado ao Index, catálogo oficial de livros proibidos pela Igreja católica romana por serem avaliados danosos à fé e imorais.

A operatividade do conceito de campo literário ampara a explicitação acerca da criação artística, visto que é passível de ser compreendida por meio do mapeamento da instituição literária e suas engrenagens. O conceito mediador do habitus alocado no campo ajuda a responder a questões centrais sobre as escolhas de Sand e as características do seu projeto criador, sua significação e constituição. Considerando que o projeto, embora seja individual, não é formulado fora da interação com os agentes e dos determinismos sociais que agem sobre a instituição literária.

O campo é visto por Bourdieu sob a ótica de uma hierarquia de poder e privilégio orquestrada por relações econômicas, simbólicas e culturais entre os indivíduos. $\mathrm{O}$ capital econômico é o termo que se refere à propriedade de recursos como renda, salários e imóveis. O status, o reconhecimento, prestígio e honra, ou qualquer outro 
privilégio de ordem de importância transita nos domínios do capital simbólico. Enquanto a totalidade de saberes e conhecimentos advindos da escolaridade são pertinentes ao capital cultural que, em sua amplitude, não dispensa a imbricação com as condições econômicas e sociais, pois assimila um grupamento de valores, conhecimentos, informações e comportamentos que influem sobre o habitus. Este último engloba um sistema de valores interiorizados que produzem diferenciações e determinam as escolhas do escritor. Compreender o funcionamento do capital cultural, pressupõe, por isso, admitir que o acesso ao mundo letrado é um privilégio resultante de condições socioeconômicas.

Assim, a posição de dominado ou dominante ocupada por um grupo ou indivíduo é definida de acordo com a soma e o arranjo de um ou mais capitais adquiridos e ou acionados no decorrer de suas trajetórias sociais. A congruência desses capitais pode ser interpretada se tomada como base a estruturação do aparelhamento cultural nas suas dimensões material, simbólica e cultural que, para Bourdieu, é a configuração do habitus.

No que concerne às categorias teóricas, o conceito de trajetória permite refletir sobre o peso dos constituintes do campo literário, o modus operandi da criação e produção 
literária. Os acontecimentos biográficos se definem como alocações e deslocamentos no espaço social e não como uma sucessão de acontecimentos ligados exclusivamente a um indivíduo com um nome próprio, como principal referência constante (BOURDIEU, 1996b, p. 81).

Fundamentado nestas definições, o autor aponta o desacerto cometido por bases teóricas que avistam as biografias sob uma matriz na qual não existe outra finalidade senão o ato de dissertar. Do contrário, faz-se necessário explicar o percurso do agente do campo levando em conta a estrutura da rede e as relações estabelecidas entre os agentes, grupos e órgãos atuantes no campo literário.

A noção de trajetória, ao situar os acontecimentos biográficos numa matriz relacional, evidencia a sua interpretação não com base nas experiências de um indivíduo único, mas operando aproximação das posições de um agente ou de um grupo do campo com os demais agentes e grupos atuantes. O indivíduo em sua trajetória no campo é explicado como concreto:

A distinção entre o indivíduo concreto e o indivíduo construído, o agente eficiente, é duplicada pela distinção entre o agente, eficiente num campo, e a personalidade, como individualidade biológica socialmente instituída pela nominação e dotada 
de propriedades e de poderes que the asseguram (em certos casos) uma superfície social, isto é, a capacidade de existir como agente em diferentes campos. (BOURDIEU, 2006a, p. 190)

No bojo dessa leitura, prioriza-se o estudo das relações, o indivíduo é compreendido através da metodologia comparativa da diferença, dos polos de crenças e exercícios opostos. Tal perspectiva permite pensar os espaços sociais como espaços de posições definidos por relações estabelecidas por capitais. O campo é, por isso, um espaço de conflito e habilidade onde os integrantes disputam o controle de um capital eficiente. Neste aspecto, Maingueneau (2006) corrobora a ideia com a reflexão de que o campo é o espaço onde as obras literárias ganham sentidos, é onde se constroem os posicionamentos doutrinas, movimentos, grupos.

Maingueneau (2006) propõe que se examinem três instâncias que gerenciam o estatuto de autoria, são elas, a pessoa, o escritor e o inscritor, as quais agem em conjunto e se encruzam. Tais instâncias são consideradas nesse estudo para análise da trajetória, considerando principalmente as distinções que separam a pessoa e sujeito do escritor:

A denominação "a pessoa" refere-se ao indivíduo dotado de um estado civil, de 
uma vida privada. "O escritor" designa o ator que define uma trajetória na instituição literária. Quanto ao neologismo "inscritor", ele subsume ao mesmo tempo as formas de subjetividade enunciativa da cena de fala implicada pelo texto [...] e a cena imposta pelo gênero do discurso: romancista, dramaturgo, contista. (MAINGUENEAU, 2006, p. 136)

Por meio dessas instâncias de subjetivação, converge a afirmativa de que não se separa a vida do autor do estatuto do escritor, que o enunciador compreendido enquanto inscritor é correlato do texto e por fim, que a subjetividade criadora não independe da atividade da escrita.

Ainda sob essa perspectiva do campo, é fundamental o entendimento de que há estados sucessivos no campo e relações objetivas que unem os participantes de um mesmo campo, é dessa maneira que a trajetória se desenvolve (BOURDIEU, 1997). O habitus se desenvolve em função desses estados sucessivos e das condições de produção do campo, por isso são incorporados ao longo da trajetória.

Em síntese, viabilizada pela gênese do campo literário de Bourdieu, com o aparato epistêmico teórico do campo, habitus, trajetória e capital, a pesquisa desenvolvida toma proveito das bases que residem na relação entre o escritor, a obra e o campo no qual George Sand estava inserida. A intenção é compreender os valores e os vínculos de força 
que residem entre essas instâncias e a forma que incidem na produção do projeto de criação sandiano.

\section{AURORE DUPIN ANTES DE GEORGE SAND}

A configuração política da época se centrava no Primeiro Império Francês comumente conhecido como o Grande Império da França ou Império Napoleônico. No plano interno, vários aspectos políticos e sociais foram mudados, a exemplo da criação do Código Civil Francês. Segundo Duby (2007) em Histoire de la France, o Código que legislava apenas sobre o direito civil reafirmou os estatutos da Revolução Francesa, conservou a retirada dos privilégios do clero e deu origem a uma nova nobreza imperial que não dispunha de direitos feudais.

O conjunto de regras civis outorgado por Napoleão privilegiava a propriedade privada e criminalizava as greves e os movimentos grevistas. No âmbito educacional, foram criados colégios e escolas superiores que se voltavam para as ciências exatas e biológicas, com objetivos que se pautavam pela formação de uma elite burguesa letrada, muito mais do que pela alfabetização das massas. O Código Napoleônico também determinava aos cidadãos o direito à propriedade privada, à liberdade individual, de pensamento, religiosa e de iniciativa privada. Foram favorecidos, de igual 
maneira, por isso, os interesses da burguesia e consolidouse o liberalismo político e econômico.

Apesar de conservar alguns princípios iluministas, o novo código civil revogava diversos direitos conquistados pela população durante a Revolução Francesa. As mulheres foram as mais atingidas pelas novas resoluções imperiais, com a retirada de todos os seus direitos e a reafirmação do princípio de submissão à autoridade masculina (pai, irmão ou marido) que será válido até 1870. Napoleão definiu sem ambiguidades o lugar da mulher na sociedade no artigo 1124 do Código, o qual estabelece que os menores de idade, as mulheres casadas, os criminosos e os doentes mentais eram excluídos de quaisquer acessos aos direitos jurídicos (CODE CIVIL, 1997).

Dentre as implicações do Código Civil sobre a condição das mulheres na sociedade francesa estava o impedimento de acesso aos liceus e universidades, de assinar contratos, de administrar seus bens e seu salário. Para que trabalhassem e fizessem viagens internacionais, era necessária a permissão marital ou do parente do sexo masculino mais próximo. Suas correspondências e relações interpessoais também estavam sujeitas ao controle do homem. Havia, ainda, forte repressão ao adultério quando praticado por mulheres e, sobretudo, a exclusão total dos direitos políticos. 
Aurore Dupin é proveniente de uma família socialmente mista: seu pai, Maurice Dupin de Francueil, era oficial do exército e neto bastardo do Marechal Maurice de Saxe, e sua mãe, Sophie-Victoire Delaborde, uma mulher do povo. Em companhia de seu pai, aprendeu os princípios igualitários da Revolução Francesa. Maurice Dupin demonstrava sempre que possível sua aceitação dos princípios iluministas, ainda que contrariassem as concepções aristocratas de sua família, como quando contraiu matrimônio contra os desejos de sua mãe.

Por ser fruto de uma educação revolucionária e portadora de uma dupla ascendência popular e nobre, Aurore Dupin ainda criança tomou consciência de sua mestiçagem social. Em consonância a isso, sua identidade política ligada a sua origem foi construída desde muito cedo. Diante do desprezo da avó paterna, Aurore de Saxe, em relação a sua mãe, a pequena se dividia entre o ambiente frequentado pelos nobres e o pequeno e pobre apartamento de sua mãe em Paris. A simplicidade e o pouco conforto do lar materno não a privaram de ter uma infância feliz, em sua imaginação era a "terra dos sonhos", por consequência, contribuíram para a assimilação da desvalida realidade do estrato social a que pertencia sua família materna. 
Ainda em sua infância, diante da morte do pai, mudouse para Nohant e permaneceu sob os cuidados de sua avó e em companhia de seu meio irmão Hippolyte Chatiron. Preocupada com a educação da neta, Aurore de Saxe a enviou para o Couvent des Anglaises, em Paris. O local, dirigido por freiras beneditinas, foi fundado em 1764, três décadas após a chegada das religiosas que fugiam da perseguição ao clérigo católico na Inglaterra.

As instituições religiosas eram responsáveis pelo ensino feminino. Neste sentido, o Código Napoleônico apenas formalizou a prática já empregada pela Igreja Católica. Essas escolas acreditavam que fornecer a mesma educação para meninas e meninos era o mesmo que confundir o que a natureza, o bom senso, a ordem e a sociedade determinam como diferente. A educação recebida no convento, por isso, preparava as meninas para a vida prática e útil, para serem boas cristãs, esposas amáveis e mães cuidadosas que se ocupam da educação de seus filhos.

Nesta época, os interesses de Aurore pelo campo artístico começam a despertar, com o gosto pela música e pelo teatro. Contudo, devido à preferência da neta pela vida silenciosa do convento e o desejo de se tornar freira, Aurore de Saxe faz com que ela retorne para a 
propriedade da família e continue seus estudos sob as orientações de um preceptor. Anos mais tarde, em 1822, após o falecimento de sua avó, Aurore Dupin se casa com François Casemir Dudevant, oficial do exército, com quem teve dois filhos, Solange e Maurice. O enlace matrimonial permitiu à futura escritora a posse da herança deixada por sua avó, conforme determinava o Código Civil. Além da propriedade de Nohant, a herança Ihe fornecia uma renda anual de cerca de sete mil francos, o que de acordo com a análise de Chanut et al. (1995) no artigo Les disparités de salaires en France au XIXe siècle, se comparado aos salários dos demais trabalhadores, era suficiente para manter uma vida confortável.

Enquanto sujeito, Aurore Dupin vivenciou desde sua infância o sentimento de injustiça. Em sua adolescência, observara a ausência de registros e memórias de sua família materna, associou o fato à condição socioeconômica da genealogia plebeia. A trajetória de Sand é movimentada, dessa forma, graças aos capitais acumulados por essa bagagem cultural e intelectual desenvolvida ainda cedo junto de seus pais e a vivencia em dois polos sociais totalmente opostos.

A escolha dos gêneros, dos temas, das personagens, e sua atuação no campo literário apontam para a preocupação 
com as pessoas do povo e aqueles que são negligenciados socialmente. Tais tipos figuram com expressividade em seus romances e permitem inferir, no âmbito do habitus, a motivação de Sand se colocar como porta-voz de discursos progressistas. Em Histoire de ma vie (1854), a escritora esclarece suas convicções sobre sua identidade e sua posição diante da história e do poder: "Je suis la fille d'un patricien et d'une bohémienne [...] Je serai avec l'esclave et avec la bohémienne, et non avec les rois et leurs suppôts" (SAND, 1854$, p. 11$)^{1}$.

\section{A TRAJETÓRIA DE GEORGE SAND NO CAMPO LITERÁRIO}

Até 1830, não havia se manifestado no âmbito político e das letras. A escritora inicia sua atividade literária diante da Revolução de Julho de 1830 ou os Três Gloriosos, uma conflagração de caráter liberal e popular, liderada pela burguesia francesa, que retirou do trono o Rei Carlos X. O ocorrido aparece como pano de fundo da narrativa no primeiro romance sandiano, Indiana (1832), publicado dois anos mais tarde.

Em 1832, é iniciada sua carreira literária com a publicação de Indiana, romance que dedica contundente crítica à sociedade patriarcal, mais precisamente à forma como a

1 "Sou a filha de um patrício e de uma cigana [...] Estarei ao lado do escravo e da cigana, e não com os reis e seus partidários" (SAND, 1854, p. 11, tradução nossa). 
mulher burguesa era tratada na estrutura matrimonial. Segundo a própria escritora na autobiografia Histoire de ma vie (1854), parte substancial de seu projeto de criação literária descortina problemas enfrentados socialmente pelo povo e pelas mulheres, movimentando-se em torno de demandas que se ajustavam à conjuntura do Estado Francês.

“Née romancier je fais des romans, c'est-à-dire que je cherche par les voies d'un certain art à provoquer l'émotion, à remuer, à agiter, à ébranler même les cœurs [...]; l'émotion porte à la réflexion, à la recherche" (SAND, 1969, p. 827)². A declaração de Sand corresponde à escolha por escrever romance, gênero que na época sofria demasiada rejeição tanto pela diversidade de conteúdo, tanto pela não padronização estrutural. Colocar-se enquanto romancista e alguém que nasceu com dom para estabelecer-se no campo literário através desse tipo de criação, demonstra o ensejo em produzir textos nos quais houvesse liberdade discursiva para comunicar suas ideias aos seus leitores, principalmente aquelas que versavam sobre a situação da mulher na sociedade e no matrimônio.

Neste contexto, são despertados em Sand diversos questionamentos e percepções acerca das diferenças de

2 "Nascida romancista, escrevo romances, isto é, procuro meios de uma certa arte provocar emoção, mexer, agitar, abalar até mesmo corações [...]; a emoção leva à reflexão, à pesquisa" (SAND, 1969, p.827, tradução nossa). 
tratamento social quando direcionado às mulheres e as dificuldades para ser uma mulher livre. O engajamento político de Sand transparece mais fortemente em parte de suas publicações a partir de 1834, ano do Segundo Levante de Lyon, período de intensa repressão política e judicial contra a oposição republicana. Convertida ao sentimento republicano, ela se recusa a manter neutralidade frente ao embate que colocaria em voga as promessas e convicções herdadas da Revolução Francesa. Para a escritora, era necessário o estabelecimento de uma república democrática que concedesse a estruturação de um estado que assegurasse a liberdade de cada um e o bem comum, visando em primeira instância enfraquecer os poderes aristocráticos.

Em consonância à adesão ao republicanismo, a romancista se torna adepta do saint-simonismo, doutrina socioeconômica e política que preconiza uma sociedade fraterna onde os membros competentes de cada área são responsáveis por administrar o país, tendo em vista a edificação de um estado próspero em termos de produção industrial, paz e liberdade. Sand desenvolve uma relação de proximidade com Lamennais ${ }^{3}$, nome importante entre os saint-simonistas, filósofo e escritor francês cujas ideias

3 Hughes Félicité Robert de Lamennais (Saint-Malo, 19 de junho de 1782 - Paris, 27 de fevereiro de 1854), foi um filósofo e escritor político francês. 
partiam da defesa da liberdade individual, preceito que é considerado fundamental para o progresso e que passarão a aparecer com mais frequência em seus romances, a exemplo de Spiridion (1843).

Em romances e publicações em revistas, Sand condenava a violência entre os homens e a propriedade que se sustenta por meio da exploração do trabalho, em detrimento da propriedade individual e intelectual, a exemplo de La Mare au Diable (1852), no qual dedica um prefácio para discutir as condições de subsistência do homem do campo. Tal movimentação em sua trajetória enquanto sujeito e agente do campo literário amplifica seu envolvimento com as causas sociais e as tentativas de participação política. As associações com os agentes do campo filosófico e literário não apenas concorreram para o entendimento de certas correntes de pensamento, bem como influíram em suas tomadas de posição quanto às temáticas e enredos que cumpriam função educadora e renovadora para aqueles que tinham acesso à leitura na sociedade francesa.

De acordo com Perrot (2005, p. 385), Sand foi uma "mestiça social" que desde muito cedo compreendeu a desigualdade social. Excluída da cidadania política, Sand, que chegou a participar de reuniões na Câmara dos Comuns em 
Paris vestida como homem, ensejou, por meio da literatura, opor-se à biologização da diferença entre os gêneros que fazia com que a divisão das esferas públicas e privadas fosse justificada por fundamentos naturalistas.

Até o fim do século XIX, a escrita de autoria feminina ainda era considerada um tabu diante do grande domínio da autoria masculina e poucas foram as mulheres que publicaram suas obras fazendo uso de seu verdadeiro nome. Sand não foi uma exceção. Em Histoire de ma vie, a autora relata desde a motivação de utilizar um pseudônimo até as implicações do uso do mesmo. Casada com Casimir Dudevant, foi impedida pela Baronesa de Dudevant de utilizar o sobrenome da família para sua primeira publicação (SAND, 1854).

O código napoleônico e os grupos conservadores da Igreja encerravam as mulheres em um espaço de submissão e restrição à educação. Sand foi uma exceção no segundo quesito, sua ascendência aristocrata lhe permitiu desfrutar do aprendizado das artes e literatura no Couvent des Anglaises e de uma educação desafiadora com seu preceptor. A escolha pela atividade da escrita foi pretexto para que fosse hostilizada entre os agentes do campo literário e de outros campos da sociedade francesa. Sob a alcunha de bas- 
bleu $^{4}$, a incompatibilidade do exercício da escrita para uma mulher, conforme pensavam os conservadores, perpetuou julgamentos quanto a sua competência enquanto escritora e atingiu a escritora em toda a sua trajetória literária. Dentre as críticas sóbrias aos seus romances, havia injúrias misóginas à sua pessoa, a exemplo daquelas proferidas pelo poeta francês Charles Baudelaire (1821-1867) e Jules Lecomte (1810-1864), romancista e jornalista (LORUSSO, 2017). A reprovação que vai de encontro a Sand persiste de outras maneiras:

O acesso à escrita, domínio sagrado, é também uma zona de afrontamentos e de controvérsias [...]. A "mulher autora", esta "pretensa literata" detestada, atrai para si todos os sarcasmos. Uma mulher que escreve, e sobretudo, que publica, é uma mulher desnaturada que prefere abrigar-se sob um pseudônimo masculino. Seu sucesso provoca escândalo: ele é depreciado. Vejamos George Sand e seus "romances rústicos". Relegados à prateleira da Biblioteca Verde para adolescentes (La Petite Fadette, La mare au Diable), eles fizeram esquecer a obra multiforme de uma escritora imensa, que redescobrimos apenas nos dias de hoje. (PERROT, 2005, p. 271)

De forma abrangente, suas obras tangenciam os parâmetros românticos e estereótipos culturais da mulher

4 Expressão difundida no século XIX para designar pejorativamente as mulheres escritoras ou qualquer mulher que se interessasse e desempenhasse algum ofício no meio intelectual e artístico. 
sedutora e imoral, da megera, da indefesa e incapaz, da mulher como anjo e outras diversas definições. Suas personagens transitam sob a égide do idealismo utópico, figurando como conscientes ou em transformação para a tomada de consciência.

Em suas primeiras publicações, as narrativas são bem situadas no tempo. Por vezes, são romances que se desenrolam tendo como pano de fundo acontecimentos históricos como a Revolta de 1830 e a Monarquia de Julho. Os personagens, muitas vezes contraditórios, são idealizados. A amante, a mulher independente ou que não aceita os jugos da sociedade não é a louca ou a megera, a mulher inocente e maltratada pelo marido não é santa ou angelical. Ambas são idealizadas em descrições e enredos que as colocam em uma estrutura que descortina as condições de sua existência limitada ao lar e engendra mulheres conscientes que, por vezes, empreendem mudanças. Os romances de Sand apresentam uma mensagem, uma reivindicação: seja pela liberdade, pelo direito ao amor, num movimento de recusa às convenções e às injustiças que o povo e as mulheres sofriam.

Em vista da configuração social que refletia diretamente na difícil legitimação das escritoras no campo literário, o emprego do pseudônimo passa a ser mais recorrente. Então, por que George Sand? Em 1830, em Paris, ela conhece Jules 
Sandeau, romancista e dramaturgo francês, com quem manterá um relacionamento amoroso durante três anos. Durante este período, escreveram e publicaram o romance Rose et Blanche (1831), cuja temática fala sobre a dor moral sofrida pelo homem e pela mulher dentro de uma concepção negativa da relação entre os dois sexos. O fato da baronesa de Dudevant, sua sogra, não lhe permitir publicar com o nome do marido leva a escritora a publicar sob o nome de J. Sand, contração do nome de seu amante (SAND, 1854). Ao redigir Indiana, a romancista enfrentou mais uma vez a problemática do nome, já que seu amante não concordava em assinar um livro cuja autoria não Ihe pertencia e, devido às represálias, o mais sensato seria permanecer no anonimato:

Le nom que je devais mettre sur des couvertures imprimées ne me préoccupa guère. En tout état de choses, j'avais résolu de garder l'anonyme. Un premier ouvrage fut ébauché par moi, refait en entier ensuite par Jules Sandeau, à qui Delatouche fit le nom de Jules Sand. Cet ouvrage amena un autre éditeur qui demanda un autre roman sous le même pseudonyme. J'avais écrit Indiana à Nohant, je voulus le donner sous le pseudonyme demandé; mais Jules Sandeau, par modestie, ne voulut pas accepter la paternité d'un livre auquel il était complètement étranger. (SAND, 1884, p. 32)

5 “O nome que eu devia colocar nas capas impressas não me preocupava muito. Em todo caso, havia resolvido guardar o anonimato. Uma primeira obra foi esboçada por mim, e refeita inteiramente por Jules Sandeau, a quem Delatouche deu o nome de Jules Sand. Essa obra 
Com a negativa de seu amante e o posterior término da relação, a escritora estabeleceu seu nome literário, optando por George como primeiro nome em alusão ao Berry - antiga província francesa que, com a reforma da administração do território francês de 1790, teve o território dividido entre os departamentos de Cher, Indre e Loiret - por meio de um nome comum aos habitantes da região. Em seu projeto de criação literária, Sand não poupou homenagens a essa terra que figura, numa dimensão de simplicidade e acolhimento, como um refúgio em meio à natureza e lugar de nostalgia. Apesar do esforço para se manter no anonimato, desde a publicação de Indiana, os críticos já supunham que se tratava de uma mulher por trás do pseudônimo. Mesmo tendo seu rosto conhecido no campo literário, Sand decide continuar a usar seu nome artístico.

Numa época em que os papéis sociais se esbarram em fronteiras que demarcam a esfera pública da esfera privada, entregando ao homem o poder de transitar ativamente na vida pública e social e relegando a mulher aos bastidores, a escritora buscou angariar capital simbólico com o apoio de relações que colaboravam para seu estabelecimento 
no campo literário. Sand transgrediu os códigos sociais da sociedade burguesa do século XIX, ao circular na esfera pública e ao almejar uma carreira de escritora. Dessa forma, por meio de associações com escritores, editores, críticos como Chales Auguntin Sainte-Beuve (1804-1869), George Sand passou a ser conhecida e posteriormente requisitada no meio literário.

Entre Sand e Baudelaire havia um embate despertado pela diferença entre as vertentes literárias seguidas por ambos (LORUSSO, 2017). Segundo o poeta, faltavam-lhe ideias morais, profundidade de juízo e delicadeza de sentimentos. Já Emile Zola encontrava nela e em seus escritos uma doce tolerância, um grande espírito de caridade, uma luta persistente (LORUSSO, 20017, p. 7). Já no século XX, Maurois (1956, p. 7), na nota preliminar da biografia Lélia ou a vida de George Sand, declara:

Quanto a Alain, falava em Sand com respeito. "Que grande mulher", dizia ele, e o seu tom de voz dava a entender que essa grande mulher era um homem eminente. Acrescentam-se a estes dois fiadores, os mestres que foram os seus contemporâneos. Reflita-se que ela inspirou Chopin e Musset; que Delacroix tinha um "atelier" em casa dela; que Balzac vinha pedir "à colega George Sand" o enredo de um de seus livros mais bonitos: Béatrix; que Flaubert a chamava "Minha prezada mestre" e chorou quando soube de sua morte; que Dostoievski via nela um escritor "quase único pela força do espirito e talento". (MAUROIS, 1956, p. 7) 
O que é um projeto de criação literária para a mulher naquele momento histórico na França? George Sand esperava da literatura o cumprimento de uma função social ou política e condenava o que chamava de "arte egoísta", aquela que é mercantilizada e está a serviço do poder e de sua manutenção, bem como a arte pela arte. Para aqueles que defendiam a arte pela arte, as obras literárias não respondiam a uma razão funcional e eram desprovidas de objetivos pedagógicos e morais. Assim, a arte deveria ser vista como autônoma e apenas em sua construção estética. Essa concepção de literatura coloca George Sand no polo oposto a Baudelaire (BOURDIEU, 1996a, p. 91).

Gustave Flaubert, grande amigo de Sand, de igual maneira, manifesta o desprezo pela arte social. Em carta a Flaubert, a escritora declara que em seus romances repousam suas filosofias, são elas que direcionam as narrativas e a existências dos personagens.

Moi, je ne fais pas de satires: j'ignore même ce que c'est. Je ne fais pas non plus de portraits ce n'est pas mon état. J'invente. Le public, qui ne sait pas en quoi consiste I'invention, veut voir partout des modèles. (SAND,1854, p. 360)

6 "Não faço sátiras: ignoro até o que é. Tampouco faço retratos, não é minha condição. Eu os invento. O público, que não sabe em que consiste a invenção, quer ver em toda parte modelos" (SAND, 1854, p. 360, tradução nossa). 
Considerando essa declaração, sua criação literária é atravessada por três grandes correntes temáticas: o romantismo sentimental, o socialismo humanitário e o gosto pelo campo. Sand visava obter do leitor, pela força da escrita, um olhar arguidor sobre o mundo social. Na ótica relacional da diferença, o estudo de seus romances revelam as marcas de uma observação da sociedade que excedia modelos e personalidades do cenário de seu contexto de produção. É possível inferir que a intenção da escritora resultou em seu reconhecimento na época e na contemporaneidade, "marcar época é fazer existir uma nova posição para além das posições estabelecidas, na dianteira dessas posições, na vanguarda, e, introduzindo a diferença, produzir o tempo" (BOURDIEU, 1996a, p. 181).

Sand teve uma importante passagem por Le Figaro em 1831, jornal fundado em 1826 cuja linha editorial era de centro-direita do liberalismo clássico ${ }^{7}$ e do conservadorismo social ${ }^{8}$. A escritora aprendeu o ofício de jornalista com o poeta, romancista e redator Henri De Latouche (1785-1851). Além de enfrentar a dificuldade com a escrita jornalística, Sand também se esforçava para

\footnotetext{
7 Corrente político filosófica fundada na crença na individualidade de cada ser e que acredita que todo homem possui direitos fundamentais.

8 Filosofia política que se opõe aos valores progressistas e defende as tradições, de forma que a ordem social deve ser mais relevante do que a liberdade do homem.
} 
seguir a mesma linha editorial do jornal de centro-direita e publicava anonimamente artigos e sátiras sobre arte e política na coluna Bigarrures (SAND, 1854).

Suas primeiras novelas foram publicadas em formato de folhetim na Revue de Paris, revista literária e artística fundada em 1829, forte concorrente da Revue des Deux Mondes. O primeiro romance integral publicado, Indiana (1832), movimentou a crítica parisiense. Sainte-Beuve, em sua coluna Varietés no Le National, escreveu uma resenha sobre o romance, destacando os elogios por parte de outros críticos e pontuando que somente uma mulher poderia, com uma escrita pouco ortodoxa redigir um enredo sobre as angústias e sentimentos vividas no matrimônio e em sociedade (SAINTE-BEUVE, 1832, 4-5).

Após seu segundo romance intitulado Valentine (1833) ser publicado por La Mode, Gustave Planche ${ }^{9}$, à época crítico da Revue des Deux Mondes, dedica-Ihe artigos nos quais expressa apreciação às obras literárias sandianas e a apresenta a Charles Buloz, diretor da revista, com quem Sand desenvolverá uma relação profissional e de amizade que perdurará por mais de quatro décadas. Pouco conhecida na época, a escritora ofereceu exclusividade de seu trabalho

9 Gustave Planche (16 de fevereiro de 1808 - 18 de setembro de 1857) foi editor e crítico literário francês com atuação nas revistas l'Artiste e a Revue des Deux Mondes, assim como em Le Journal des débats. 
à revista, que recepcionou diversos romances sandianos como Lettres d'un Voyageur (1834-1836), Mauprat (1837), Spiridion (1839), Mademoiselle La Quintinie (1863) e Césarine Dietrich (1870).

A Revue des Deux Mondes foi fundada em 1829 por Prosper Mauroy e Ségui-Dupeyron, segundo o site da Revue ${ }^{10}$, com o propósito de publicar estudos comparados sobre os sistemas políticos e administrativos de países da Europa e da América e a desempenhar a função de um jornal de viagens. Contudo, em 1831, mudanças ocorrem mediante a contratação de François Buloz para editor chefe, as publicações serão então dirigidas para o âmbito das artes e literatura.

Em sua estreita relação com a imprensa, George Sand escreveu inúmeros artigos sobre política, arte e literatura, além de romances e folhetins. Sua presença no mundo editorial se consolidou com seu contrato junto à Revue des Deux Mondes e sua associação a diversos jornais e editoras. Merece destaque a Calmann-Lévy, editora criada em 1836, como um pequeno gabinete de peças teatrais e que, com seu crescimento, veio a publicar textos de Théophile Gautier (1811-1872), Alexandre Dumas Fils (1824-1895), Charles Baudelaire, Gustave Flaubert, (1821-1880), Victor Hugo

10 HISTOIRE DE LA CRÉATION. Revue des Deux Mondes. Disponível em: https://www. revuedesdeuxmondes.fr/article-revue/histoire-de-la-creation/. Acesso em: 26 dez. 2018. 
(1802-1885), Alphonse de Lamartine (1790-1869), Stendhal e Gérard de Nerval (1808-1855). Contudo, de acordo, a fidelidade editorial da escritora se manteve à Revue des Deux Mondes (THÉRENTY, 2004, p. 79).

Com seu prestígio na cena pública e literária, a senhora de Nohant criou a Revue indépendante em 1841 em companhia de Pierre Henri Leroux ${ }^{11}$ et Louis Viardot ${ }^{12}$. Sand tinha consciência do poder da imprensa sobre a formação da opinião pública e esteve dedicada principalmente a temas em torno da fraternidade e da recusa à violência. O periódico privilegiava publicações sobre literatura e política, e a maior parte de seus artigos eram assinados por pseudônimos.

A escritora participou da criação de vários jornais como L'Éclaireur de L'Indre, jornal local de oposição na província de Berry fundado em setembro de 1844 cujo objetivo era defender as causas do povo, como o acesso a bens básicos e dar voz à opinião pública. Fato semelhante à sua atuação em La Cause du peuple, jornal popular fundado pela autora em 1848 que teve apenas três números publicados.

A intersecção do ofício jornalístico de Sand com sua trajetória no campo literário esboça não apenas algo comum entre escritores da época. Ao tomar a palavra por

\footnotetext{
11 Pierre Leroux (1798-1871) foi um filósofo e político francês.

12 Louis Viardot (1800-1883) foi escritor, crítico literário e tradutor.
} 
meio de artigos, ensaios, críticas, cartas abertas e romance folhetim, Sand se esforça em torno do desenvolvimento do capital simbólico, cultural e econômico. Conhecer e se fazer conhecida, dialogando com seus pares e contemporâneos ao mesmo tempo em que se desenvolvem competências diversas são fatores definidos pela necessidade de expor e defender suas ideias acerca do mundo social em um espaço público e de maior acesso devido à pauta informativa.

Sand publicou artigos acolhidos por outros periódicos, a exemplo de La Presse, La Réforme ${ }^{13}$, Le Constitutionnel 14 e Le Temps ${ }^{15}$, devido a diversas divergências contratuais e intelectuais entre a escritora e Buloz, diretor da Revue des Deux Mondes, cuja trajetória social intercruza com a de Sand (THÉRANTY, 2004, p. 81). Buloz nasceu em 1803, o oitavo filho de uma família do povo que chega à redação da revista por meio de contatos provenientes de sua antiga profissão: era encarregado de chefiar um ateliê de composição tipográfica ligado diretamente à imprensa. O estabelecimento deste novo editor é marcado por sua iniciativa bem-sucedida de privilegiar o movimento

13 La Réforme foi fundado por Alexandre Ledru-Rollin em 1843. O Jornal defendia um ideário republicano e de cunho social, tendo em vista o bem-estar da população francesa

14 Le Constitutionnel é um jornal fundado durante os Cent Jours (10 de março de 1815 - 8 de julho de 1815) por Fouché, político francês.

15 Le Temps foi um jornal diário francês fundado em 15 de outubro de 1829 por Jacques Coste, de cunho político, científico, literário e industrial de aspiração liberal. 
romântico e reunir jovens e homens das letras ainda pouco conhecidos como Gustave Planche (1808-1857) e SainteBeuve, que assumem seções de crítica e Alexandre Dumas Fils, Prosper Mérimée (1803-1870), Alfred de Vigny (17971863), Alfred de Musset e Sand que publicam romances, poemas e peças de teatro.

O contrato com a Revue des Deux Mondes assegurou a estabilidade financeira da escritora que, a partir de então, contribuía regularmente com a revista, enviando trinta e duas páginas a cada seis semanas pela soma de quatro mil francos no total (SAND, 1854, p. 74). Neste contexto, é expressivo que as relações com esses agentes trouxessem à escritora contribuições sobre a conquista de capitais.

A vida pessoal da romancista fora pretexto para afrontas e críticas que extrapolavam o domínio literário e atingiam a sua condição de mulher. Seus relacionamentos amorosos eram um dos pontos que ocasionavam tais considerações, visto que se vinculou afetivamente com diferentes amantes, alguns enquanto ainda era casada judicialmente com Casimir Dudevant, o que chocava a moral daquele tempo. Dois relacionamentos marcaram a trajetória da escritora, ao Ihe renderem novas publicações e o conhecimento de outros escritores. 
O relacionamento com Alfred de Musset, poeta, novelista e dramaturgo francês, um dos expoentes mais conhecidos do Romantismo, teve início durante um jantar oferecido pela Revue des Deux Mondes, em julho de 1833, sendo Sand, na ocasião, a única mulher presente. A aproximação foi seguida de cartas cujos temas eram pertinentes ao campo literário. A escritora lhe enviou o manuscrito de Lélia, romance no qual um dos personagens, Stenio, fora inspirado em Musset, através das leituras de seus livros, antes mesmo que ela o conhecesse. Seguindo o costume da época, o casal viajou à Itália, país que despertará o encantamento da escritora e se tornará sua segunda pátria. Durante a viagem à Italia, Sand e Musset se encontram com escritor e novelista realista Sthendhal (1783-1842). Em Histoire de ma vie, George Sand relata como foram os dias passados ao seu lado:

Je causais avec lui, le trouvais fort aimable. Il se moqua de mes illusions sur l'Italie, assurant que j'en aurais vite assez et que les artistes à la recherche du Beau en ce pays étaient de véritables badauds. Je ne le crus guère voyant qu'il était las de son exil. (SAND, 1854, p. 63) 16

16 "Conversava com ele, achava que era muito amável. Ele zombou de minhas ilusões sobre a Itália, assegurando que eu logo estaria enfadada e que os artistas em busca do belo naquele país eram verdadeiramente viajantes curiosos e superficiais. Eu não acreditei em quase nada por perceber que ele estava cansado de seu exílio" (SAND, 1854, p. 63, tradução nossa). 
No que parece fadigada de sua companhia, Sand declara sua aversão e o julga como um escritor mediano. Tais declarações provocam a antipatia de Sthendal que, mais tarde, será um de seus críticos mais ferozes ao lado de Baudelaire. O relacionamento com Musset dura pouco mais de um ano e meio, apesar de diversas separações. Sand publica em 1859, dois anos após a morte de seu antigo amante, Elle et lui, romance com nuances autobiográficas que descortina fatos vivenciados no decorrer do relacionamento: as inconstâncias, desavenças e projetos de suicídio.

Em 1836, a vida pessoal de Sand toma nova dimensão, posto que consegue, através da representação de seu advogado Michel de Bourges, a separação judicial de Casimir Dudevant e a guarda de seus dois filhos. Dois anos depois, em 1838, inicia um relacionamento com o musicista Frédéric Chopin, união que perdurará por dez anos. Devido aos cuidados com a saúde de Chopin e a proximidade com os filhos, Sand alternava sua residência entre Nohant e Paris.

Neste momento, a romancista se liga a escritores da esquerda literária e política, entre eles estão Louis Blanc (1811-1881), político e socialista francês que teve importante participação na Revolução de 1848 graças às 
ideias construídas em associação entre liberais e socialistas para a derrubada da monarquia, e o historiador, escritor e homem político Henri Martin (1810-1883). É por meio deste grupo que conhece Pierre Leroux, em sua companhia e orientação, desenvolve sua postura de militante progressista e republicana.

Pouco depois, em 1837, Sand publica Mauprat em folhetim pela Revue des Deux Mondes, romance histórico, filosófico e de aprendizagem cuja ação se desenvolve durante a Revolução Francesa. Durante o mesmo ano, Sand reescreve Lélia a fim de estruturar um desenlace menos trágico e menos confrontador para que essa segunda versão não sofresse uma nova censura do Index, a lista de publicações cujas leituras eram proibidas pela Igreja Católica.

\section{LEGITIMIDADE, ESTRATÉGIAS E CAPITAIS}

Dentre as estratégias de Sand para compor seu ethos e fortalecer sua legitimidade no campo literário está a vestimenta masculina usada para circular principalmente em Paris. No volume 8 de Histoire de ma vie (1856), Sand explica as razões pelas quais optou pelo uso de roupas reconhecidas socialmente para época como masculinas. Ao se mudar para Paris e iniciar sua trajetória literária, enfrentou limitações financeiras e dificuldades para caminhar nos 
pavimentos da nova cidade. Segundo a escritora, seus calçados não resistiam mais do que dois dias de caminhada, caía constantemente e não conseguia levantar seu vestido (SAND, 1856, p. 116). A exaustão sobre esse aspecto e o ato de observar a rotina de seus jovens amigos que tinham acesso a eventos literários e políticos, teatros, museus e clubes, corroboraram para que ela tomasse uma decisão em definitivo: apresentar-se publicamente vestida em trajes masculinos:

Balzac disait: "On ne peut pas être femme à Paris à moins d'avoir 25 mille francs de rente". Et ce paradoxe d'élégance devenait une vérité pour la femme qui voulait être artiste. [...] Cette idée me parut d'abord divertissante et très-ingénieuse. (SAND, 1856, p. 215-216) ${ }^{17}$

Os espaços sociais e, consequentemente, o campo literário não foram estruturados pensando na participação das mulheres. A interlocução com Balzac esboça a realidade sobre os padrões do vestuário da mulher parisiense, o que fomenta a percepção de Sand sobre a vida econômica das escritoras da época, mesmo que de pouco a pouco fosse possível conquistar certa autonomia financeira. Por isso,

17 Balzac dizia: "Não se pode ser mulher em Paris a menos que tenha 25 mil francos de renda". E esse paradoxo de elegância tornava-se uma verdade para a mulher que desejava ser artista. Essa ideia me pareceu, de início, divertida e muito engenhosa." (SAND, 1856, p. 215 216, tradução nossa). 
está presente nessa decisão a estrutura do campo literário francês do século XIX que, segundo Mollier (2006, p. 332) fazia com que as mulheres tivessem as piores dificuldades para trabalhar como escritoras, para além das rejeições e julgamentos como bas-bleu, grande parcela não desfrutava de um direito proporcional à venda de seus volumes.

Ao falar sobre a maneira com que se vestia, a escritora utilizava o adjetivo déguisée que quer dizer disfarçada, colocar roupa para se tornar desconhecida, fazer com que pareça ser outro. Sand ensejava não apenas economizar seus rendimentos, mas frequentar lugares cujo acesso era restrito ao se passar por homem:

Je courais par tous les temps, je revenais à toutes les heures, j'allais au parterre de tous les théatres. Personne ne faisait attention à moi et ne se doutait de mon déguisement. Outre que je le portais avec aisance, l'absence de coquetterie du costume et de la physionomie écartait tout soupçon. (SAND, 1856, p. 217) $)^{18}$

George Sand relata seu contentamento em poder frequentar lugares e transitar, sozinha ou rodeada de seus amigos, sem que praticamente ninguém a reconhecesse enquanto mulher. No século XIX, a identificação e distinção

18 "Eu corria todo o tempo, voltava todas as horas, ia ao parterre de todos os teatros. Ninguém prestava atenção em mim e não duvidava de meu disfarce. Além de portá-lo com facilidade, a ausência de elegância do traje e da fisionomia afastava qualquer suspeita" (SAND, 1856 , p. 217, tradução nossa). 
dos gêneros era fortemente notada pelas vestimentas. Em primeira instância, é por meio do corpo que é convencionado o espaço que será ocupado pelo sujeito, a vestimenta que molda esse corpo é um objeto que identifica o gênero, classe e grupo social. A roupa masculina funcionava, por isso, como uma espécie de passaporte para sua entrada na vida pública, essa era a condição para que pudesse se deslocar livremente. Com ou sem o intuito de chocar, o ato de Sand evidencia demasiado imperativo para que se ocupassem esses espaços e fosse iniciado seu engajamento político nesse mundo reservado aos homens. A consciência da escritora acerca das limitações e enfrentamentos da mulher para a aquisição da igualdade de gênero que será confirmada em seus romances e correspondências é performada fisicamente neste disfarce que incluía hábitos como beber e fumar, os quais eram escandalosos para a época.

O escritor e historiador Jean-Paul Clément no artigo George Sand: le scandale du pantalon publicado na Revue des Deux Mondes aponta que para portar trajes masculinos, as mulheres necessitavam de uma permissão ou incorreriam na ilegalidade, visto que a lei do travestimento ${ }^{19}$ sancionada pelo 16 brumário ano IX em 1800 exigia que toda mulher que estivesse travestida portasse uma autorização emitida pelo Departamento de

19 Archives de la Préfecture de Police de Paris. Dossier D/B 58. 
Polícia. Como principal ordem, a lei declarava: "Toute femme désirant s'habiller en homme doit se présenter à la préfecture de police pour en obtenir l'autorisation, et celle-ci ne peut être donnée qu'au vu d'un certificat d'un officier de santé" (PELLEGRIN e BARD, 1999, p. 299) ${ }^{20}$.

Sabe-se, com isso, que poucas foram as mulheres que conseguiram essa permissão e que na época havia trabalhadoras que usavam uniformes no qual a calça era peça indispensável. Havia, nesta lei, a reafirmação de tópicos do Código Civil os quais compreendiam a mulher sob a ótica da biologização do gênero e dos determinismos sociais que dispunham para os homens uma vestimenta mais prática e propícia para a vida pública.

Christine Bard (2010), em entrevista sobre seu livro Une histoire politique du pantalon à l'humanité explica que a calça era um símbolo de poder e, por isso, os homens dispunham dessa veste fechada, protetora e de fácil mobilidade para seus corpos, o que se opõe às propriedades da saia. Quando George Sand, de acordo com Bard (2010), assume sua predileção pela calça, ela se torna "uma espécie de estereótipo da mulher das letras masculinizada e livre", diante disso a escritora passa a

20 "Toda mulher que deseja se vestir como homem deve se apresentar na prefeitura de polícia para obter a autorização, e isso só pode ser dado com base em um certificado de um oficial de saúde" (PELLEGRIN e BARD, 1999, p. 299, tradução nossa). 
representar um modelo de liberdade e de reinvindicação de igualdade com os homens.

Ao considerar que o ethos possibilita pensar no processo e em tudo que está envolvido na adesão dos coenunciadores ao que é apresentado discursivamente, a forma como Sand apresenta sua corporalidade no campo literário e em outros campos, incluindo em sua vida privada incide na apreensão de seu ethos pré-discursivo. Tanto a vestimenta quanto o pseudônimo e ações presentes e futuras como seu divórcio, amantes, as críticas ao matrimônio, as convicções socialistas e outros aspectos de sua vida privada são elementos localizados no plano extra discursivo que estão no imaginário coletivo acerca de sua figura pública.

Neste sentido, cabe considerar a instância autoral do escritor, se valendo do saber que ela é atravessada pelas demais, sujeito e inscritor. O sujeito Aurore Amandine Dupin, a partir do momento que se converte no agente do campo literário George Sand, terá sua imagem e caráter vinculados à personalidade pública da escritora e suas ações são indicadores de sua postura. De acordo com Maingueneau (2014, p. 271), o ethos abarca mais que a dimensão textual, está atrelado às representações coletivas que se desenvolvem em termos de "determinações físicas e psíquicas" que delegarão o caráter e a corporalidade do enunciador. 
A corporalidade está fortemente atrelada à maneira de se vestir e a como esse corpo físico se movimenta no espaço social, dessa maneira as representações coletivas incidem diretamente sobre a percepção da corporalidade e da compleição psicológica pelo público que avaliará os estereótipos de comportamento que serão ou não confirmados pelo projeto de criação literária da escritora (MAINGUENEAU, 2006, p. 272).

A maneira como Sand se apresenta possibilita a acepção de uma outra identidade que permite se desvincular dos determinismos sociais que recaem sobre o gênero. As roupas e o pseudônimo são imperativos para a época e possuem claramente uma função identitária, por isso não se limita a uma questão de conforto e econômica, é de igual maneira política. Isso responde a questões em torno da permanência do pseudônimo mesmo quando já era de conhecimento comum quem era ela e seu nome de batismo. Diante do conjunto de condições sociais que impulsionam a escritora a se amparar nos estereótipos de comportamento da mulher livre e transgressora da moralidade, é coerente afirmar que tais escolhas definem seu posicionamento no campo literário. Em um duplo movimento entre as ações da romancista diante da sociedade e de agentes que a avaliam, 
é estabelecida a primeira impressão acerca da natureza do trabalho criativo, sendo um importante determinante para seu projeto de criação literária.

São criadas, dessa forma, uma série de antecipações e expectativas sobre o teor e temáticas de suas publicações, o olhar do público se volta a um indivíduo que para além do estereótipo simbólico da igualdade de direitos entre os gêneros. As possíveis antecipações com base no ethos pré-discursivo dirigem o leitor sobre a escolha ou recusa à leitura e ao direcionamento da interpretação textual. Neste sentido, o ethos pré-discursivo engendrado na junção da corporalidade e do caráter de Sand chegam antes daquele, da imagem construída através do discurso do enunciador, do inscritor.

Ser encarada como mulher livre e fora das normas sociais em outros campos sociais era danoso para a sua imagem de escritora. Para Sand, a liberdade não implicava o abandono ao amor e à família, mas unicamente a escolha acerca de suas vidas, autonomia econômica, de pensamento e política. Não é ao acaso que fora censurada pela Igreja e considerada, principalmente no início da sua trajetória como uma leitura danosa às jovens. Em La Mise en Scène de la Vie Quotidienne, o antropólogo e sociólogo Erving Goffman (1973) apresenta 
cada indivíduo como um ator que desempenha um papel social de maneira que visa convencer a si mesmo e aos demais de sua interpretação: "I'individu en présence des autres fournit nécessairement une interprétation de lui-même. Le sexe, l'âge, la classe sociale, l'état de santé, la nationalité, toutes ce données sont transmises, en grande partie sans y penser" (GOFFMAN, 1973, p. 129) ${ }^{21}$.

O termo-fachada designa os acessórios que permitem ao ator desempenhar seu papel, como as vestimentas e o discurso. Há na decisão de Sand em se deslocar no espaço público em vestes masculinas, a idealização de se passar uma imagem outra daquela da esposa e as quais as mulheres estavam vinculadas. A George Sand torna-se a identidade da escritora, tanto o nome quanto suas roupas reivindicam o divórcio aos estereótipos de gênero e aos determinismos sociais, impondo uma identidade artística que excede o campo literário e cria ethé pré-discursivos que orientam os leitores sobre sua corporeidade e caráter que no polo positivo atua como a artista intransigente, livre e defensora da liberdade das mulheres, da igualdade civil e no matrimônio. O mesmo pode ser considerado pelo viés negativo, posto que contraria as convenções sociais e os códigos da época.

21 "O indivíduo em presença de outros fornece necessariamente uma interpretação dele mesmo. O sexo, a idade, a classe social, estado de saúde, a nacionalidade, todos esses dados são transmitidos, em grande parte sem pensar" (GOFFMAN, 1973, p.129, tradução nossa). 
Por meio do seu acesso à imprensa, em 1843, Sand se envolve no caso denominado Affaire Fanchette, na defesa de uma jovem encontrada errante que, por decisão do governo, foi internada em um hospício, sendo vítima de sucessivos maus tratos. Ao publicar diversas cartas na Revue Indépendante em 1843, a escritora conseguiu com que a justiça se pronunciasse sobre o caso. Essa ação pode ser compreendida como o uso de seu capital simbólico e desenvolvimento do mesmo.

Em seu engajamento político, Sand esteve ligada à Revolução de 1848. Comumente conhecida como a Primavera dos povos, as revoluções que se espalharam pela Europa Central e Oriental se opunham aos governos monárquicos autocráticos, às crises econômicas e à ausência de representação política para o povo. Com o fim da Revolução de 1848, Sand afastou-se da cena política e reaparece apenas em 1851, manifestando-se contrária ao golpe de estado de Louis-Napoléon Bonaparte (1808-1873) com quem se correspondia em concordância com sua eleição e na tentativa de ajudar prisioneiros políticos e exilados (SAND, 1883). Por essa razão, em carta endereçada a Jules Hetzel no dia 20 de fevereiro de 1852, Sand declara a sua demissão da vida política e justifica a motivação de estabelecer comunicação com agentes do poder (SAND, 1883, p. 292). 
É nesse momento que Sand estabelece vínculo com Victor Hugo 22 , com quem manteve correspondência durante quinze anos, até o fim de sua vida, mesmo sem nunca têlo encontrado pessoalmente. A relação epistolar vai além da relação política e literária que se desenvolve através da admiração e das críticas que trocavam sobre suas publicações. Em 1854, prestes a completar seis anos, a filha mais nova da escritora, Jeanne-Gabrielle-Solange, falece. É Victor Hugo quem lhe dá apoio, compartilhando da mesma dor devido à perda de sua filha Léopoldine Hugo (1824-1843).

Em Le Dernier Amour de George Sand, Bloch-Dano (2010) narra o último relacionamento amoroso de George Sand com Alexandre Manceau, amigo de seu filho Maurice, gravador ${ }^{23}$ e filho de comerciantes com quem a romancista viverá de 1849 a 1865, ano da morte de Manceau. Durante esses quinze anos, Sand publicou aproximadamente cinquenta romances e peças teatrais.

Sand publica pela última vez em 1876 na Revue des Deux Mondes, ano de sua morte, o final de La Tour de Percemont, novela que tem como tema a Comuna de Paris

22 Victor Hugo (1802-1885) foi poeta, dramaturgo, romancista e homem político. Por ser participante de um comitê de resistência contra o regime do Segundo Império, cinco dias após o golpe de estado perpetrado por Louis-Napoléon Bonaparte a quem ajudou eleger, Hugo vai para Bruxelas, dando início a um exílio de mais 18 anos que inclui mudanças de residência para Lersey e Guernesey.

23 Artista que executa seu trabalho de criação ou aquilo que é demandado sobre metal, pedra, madeira ou material sólido. 
(1871) e a Terceira república (1871-1890). Junto à defesa da liberdade das mulheres, a romancista esteve em busca de uma sociedade mais justa e humanitária. Para além de uma mudança no código civil, acreditava que as mulheres eram capazes de contribuir para o progresso por meio da participação política e do acesso à instrução. Ela se torna, pois, militante do progresso, das ideias republicanas e da igualdade. De acordo com essas conviç̧ões, reedita obras já publicadas e escreve romances até o fim dos seus dias, a exemplo de Lélia e Spiridion.

\section{CONSIDERAÇÕES FINAIS}

A estrutura do campo literário francês do século XIX impunha diversos impedimentos e enfrentamentos de gênero para as escritoras, vencê-los dependia não apenas da competência escrita, mas de diversas estratégias como a associação com os agentes corretos, a incorporação de habitus que corroboram para a construção de uma imagem positiva diante dos campos sociais e de estéticas que atravessam gerações, como observado na trajetória de George Sand.

Tanto sua herança aristocrática, quanto os rendimentos que obtinha com a publicação de suas obras e a participação em jornais the asseguraram a posse de capital econômico. 
É graças a ele que George Sand tem acesso à educação e, consequentemente, ao capital cultural que sustenta as suas diversas posições no campo literário. As ligações com escritores de diferentes estéticas e pensamentos a respeito da literatura também acrescentam conhecimento ao seu capital cultural. Essas ligações com os agentes do campo estão no cerne das trocas que orientam as escolhas temáticas e os tratamentos estéticos dedicados aos romances. Tendo em vista que seu projeto de criação tem a duração de mais de quatro décadas, Sand presenciou e vivenciou a estética de diferentes gerações, bem como as lutas no campo. Em conformidade a esse dinamismo, suas criações esboçam os momentos definitivos em sua trajetória.

Seu reconhecimento em posição de legitimidade é ocasionado, dessa forma, pela junção desses capitais adquiridos e acumulados ao longo de sua trajetória literária. George Sand estava constantemente buscando situar-se diante das normas da instituição literária, fosse por meio do contato com os grupos, os editores e por suas tomadas de posição, assegurando assim seu capital simbólico.

\section{REFERÊNCIAS}

BARD, Christine. Une histoire politique du pantalon. Paris: Le Seuil, 2010. BLOCH-DANO, Evelyne. Le dernier amour de George Sand. Paris: Grasset, 2010. 
BOURDIEU, Pierre. As regras da arte. São Paulo: Companhia das Letras, 1996 .

BOURDIEU, Pierre. Razões práticas: sobre a teoria da ação. Tradução de Mariza Corrêa. Campinas: Papirus Editora, 1996b.

BOURDIEU, Pierre. Méditations pascaliennes. Paris: Le Seuil, 1997. Disponible sur: https://www.istitutosvizzero.it/wp-content/ uploads/2018/10/Bourdieu-cap.4.pdf. Consulté le: 08 fév. 2021.

CHANUT, Jean-Marie et al. Les disparités de salaires en France au XIX e siècle. Histoire \& Mesure. Paris: Consommation. v. 10, n. 3-4, p. 381-409, 1995.

CODE CIVIL. Textes antérieurs et version actuelle, Paris: GarnierFlammarion, 1997. Disponible sur: https://www.legifrance.gouv.fr/codes/ texte_Ic/LEGITEXT000006070721/2021-02-14. Consulté le: 02 fév. 2021. DOMINGUES, José Maurício. Teorias sociológicas no século XX. Rio de Janeiro: Editora Record, 2001.

DUBY, Georges. Histoire de la France: des origines à nos jours. Paris: Larousse, 2007. Disponible sur: https://books.yossr.com/fr/histoire-dela-france-duby. Consulté le: 02 févr. 2021.

GOFFMAN, Erving. La mise en scène de la vie quotidienne. Tome 1. La présentation de soi. Paris: Editions de minuit, 1973.

LORUSSO, Silvia. La misogynie littéraire. Le cas Sand. Revue italienne d'études françaises, 2017. Disponible sur: https://journals.openedition. org/rief/1473. Consulté le: 27 déc. 2018.

MAINGUENEAU, Dominique. O discurso literário. Tradução de Adail Sobral. São Paulo: Contexto, 2006.

MAUROIS, André. Lélia ou a vida de George Sand. Tradução de Olga Biar Laino. São Paulo: Companhia Editora Nacional, 1956.

MOLLIER, Jean-Yves. Les Femmes auteurs et leurs éditeurs au XIX siècle: Un long combat pour la reconnaissance de leurs droits d'écrivains. Revue historique, Paris, n. 2, p. 313-333, 2006. Disponible sur: https://www.cairn. info/revue-historique-2006-2-page-313.htm. Consulté le: 26 jan. 2021. 
PELLEGRIN, Nicole Pellegrin; BARD, Christine. Femmes travesties: un "mauvais" genre. Clio, v. 10, 1999. Disponible sur: https://books.google.fr/ books?id=Nn6ZA352EeQC\&printsec=frontcover\#v=onepage\&q\&f=false. Consulté le: 1 févr. 2021. PERROT, Michelle. As mulheres ou os silêncios da história. Tradução de Viviane Ribeiro. Bauru: EDUSC, 2005.

SAINTE-BEUVE, Charles. Indiana par George Sand. Le National, Paris, n. 279, 5 octobre, p. 4-5, 1832.

THÉRENTY, Marie-Ève. Ne nous séparons pas, nous devons finir ensemble: George Sand, François Buloz et la Revue des Deux Mondes. Revue des deux Mondes, Paris, n. 9, septembre, p. 79-90, 2004. Disponible sur: https://www.revuedesdeuxmondes.fr/article-revue/nenous-separons-pas-nous-devons-finir-ensemble-george-sand-francoisbuloz-et-la-revue-des-deux-mondes/. Consulté le: 08 fév. 2021.

\section{Daiane Basílio de Oliveira}

Doutoranda pela UFRJ, Letras Neolatinas; Literaturas de língua francesa. Bolsista CAPES.

Grupo de estudos Arte Realidade Sociedade (Fundação Biblioteca Nacional) do Programa de Pós-graduação em Letras Neolatinas da UFRJ. Email: professoradaiane01@gmail.com Lattes: https://lattes.cnpq.br/0532825874951258 ORCID iD: https://orcid.org/0000-0003-1678-3911 